\title{
Determinants of Local Original Income The Era of Special Autonomy for the Government of Aceh Province
}

\author{
Lestari Sukarniati ${ }^{1, a^{*}}$; Firsty Ramadhona Amalia Lubis ${ }^{2, a}$ \\ 1 lestari.sukarniati@ep.uad.ac.id; ${ }^{2}$ firsty.ramadhona@ep.uad.ac.id \\ a Faculty of Economics and Business, Ahmad Dahlan University \\ * corresponding author
}

\section{ABSTRACT}

Article history

Received 2021-02-02

Revised 2021-03-17

Accepted 2021-03-18

Keywords

Special Autonomy

Financial Resources

Government Spending

Local Revenue

The Total Population
Aceh's special autonomy status allows the province to be able to obtain a larger percentage of financial resources to finance its development. The purpose of this study was to determine the influence of government spending, GRDP, and population in increasing Aceh's local revenue. This study uses a quantitative approach, the analysis tool used is panel data regression which is processed using Stata. The results of the study prove that government expenditure, GRDP, total population have a positive and significant effect on the local revenue of Aceh Province for the period 2011-2018.

\section{Introduction}

One of the causes of regional economic inequality in Indonesia during the New Order government was Law Number 5 of 1974 concerning the principles of governance in the regions. In its implementation, the central government is too dominant in controlling and controlling almost all sources of regional income which are determined as state revenues, including income from natural resources owned by the regions. Limitations in utilizing the wealth they have cause regions to have limitations in improving the welfare of their people and in the end lead to inequality between regions.

The gap between regional governments can be reduced if the policy changes from a centralized development system to a decentralized development system by issuing Law Number 33 of 2004 concerning the financial balance between the central and regional governments. Furthermore, development in the regions is aimed at increasing the level of people's welfare by providing opportunities for each region to become an autonomous 
region.

The issuance of the above law causes level II regions in Indonesia to finance the development of their respective regions without waiting for subsidies from the central government. Since then, the regions have the authority and responsibility to carry out the interests of the people, can run their government, and carry out the broadest possible autonomy, unless government affairs stipulated by law become the affairs of the central government. With this law also the regional government is allowed to be able to stipulate regional regulations and other regulations to support the implementation of regional autonomy under the principles of regional autonomy, government administration, and services to the community based on the principle of decentralization.

Sources of regional funds consist of Regional Original Income, Balanced Funds (DBH, DAU, and DAK), and regional loans, deconcentration. The first three sources are directly managed by local governments through the APBD, while the others are managed by the central government in collaboration with local governments (Halim, 2016)

The Government of Aceh has played an important role in the Indonesian economy since the signing of the peace agreement in August 2005 and the successful regional head elections in August 2006. A total of 23 districts or cities in Aceh have valuable momentum to improve the quality of life of the people by improving access to quality education., better health services and opportunities for economic development and to ensure that these funds are managed wisely for the benefit of all Acehnese people. This efficient, transparent, and effective management of public resources has great potential to transform Aceh Province into a more prosperous one.

The transition from a centralized system to a decentralized one occurred in conditions of various capacity limitations, such as limited understanding of the transition of power and responsibility and regarding the transition of public resource management from the central government to regional governments.

One of the important criteria for realizing a region's ability to regulate and manage its household is the self-supporting ability in the financial sector. Aceh's special autonomy status has provided a separate opportunity for the Province to see a greater percentage of financial resources for local governments. The absence of sufficiently systematic information regarding both qualitative and quantitative how this fiscal decentralization is managed by districts has become a trigger for developing a measurement framework for local governments in Indonesia. In other words, financial factors are an essential factor in measuring the level of regional capacity to implement their autonomy (Halim, 2016).

According to the 2007 Aceh, public financial management capacity for effective financial 
management in the local government of Aceh is essential for the achievement of long-term development goals. Several factors are limiting financial management capacity in Aceh, including the rapid decentralization of Indonesia which is the transfer of fiscal responsibility and the transfer of financial resources to local governments not followed by an increase in the capacity of local governments to manage these resources.

The realization of district / municipal original revenue in Aceh has slightly improved from year to year, this is reflected in an increase in the percentage of regional original revenue from 2016-2018 which is shown in the Table 1.

Table 1. Realization of Original Local Government Revenues in Aceh Regencies or Cities 2016-2018 (million rupiahs)

\begin{tabular}{|c|c|c|c|}
\hline Districts & 2016 & 2017 & 2018 \\
\hline Banda Aceh & $258,591,409,660.00$ & $270,170,805,360.00$ & $246,272,150,480.00$ \\
\hline South Aceh & $125,989,165,878.83$ & $140,751,362,340,70$ & $151,961,434,830.97$ \\
\hline Lhokseumawe & $56,348,631,400.00$ & $62,979,495,103.85$ & $65,610,426,908.60$ \\
\hline Northern Aceh & $388,850,936,086.81$ & $202,092,003,328.00$ & $299,541,200,896.00$ \\
\hline Langsa & $121,369,467,375.72$ & $120,138,956,032.87$ & $121,358,576,034.93$ \\
\hline East Aceh & $94,337,443,632.42$ & $158,492,371,449.82$ & $169,455,864,158.29$ \\
\hline Aceh Tamiang & $114,051,092,363.75$ & $116,246,212,753.70$ & $128,914,585,324.92$ \\
\hline West Aceh & $140,614,480,000.00$ & $161,743,458,000.00$ & $150,499,050,000.00$ \\
\hline Aceh Besar & $135,284,494,840.00$ & $145,464,468,480.00$ & $159,480,168,137.63$ \\
\hline Aceh Jaya & $45,774,374,000.00$ & $52,599,501,000.00$ & $58,624,901,000.00$ \\
\hline Pidie & $24,948,945,3840.00$ & $267,608,101,030.00$ & $237,201,958,010.00$ \\
\hline Pidie Jaya & $45,986,244,000.00$ & $47,409,466,000.00$ & $57,324,815,000.00$ \\
\hline Bireuen & $186,162,575,752.23$ & 192.939 .858 .236 .27 & $179,476,248,778.22$ \\
\hline Bener Meuriah & $66,454,059,144.63$ & $82,038,407,023.70$ & $67,961,546,855$ \\
\hline Simeulue & $48,614,164,736.00$ & $61,095,183,850.00$ & $63,146,021,910.00$ \\
\hline Central Aceh & $156,797,291,510.00$ & $162,880,726,000.00$ & $150,818,710,380.00$ \\
\hline Sabang & $49,602,492,605.34$ & $47,776,631,104.80$ & $31,676,892,439.54$ \\
\hline Abdya & $77,618,650,000.00$ & $91,571,490,000.00$ & $83,468,000,000.00$ \\
\hline Subulussalam & $42,314,514,320.00$ & $56,519,514,120.00$ & $38,955,598,640.00$ \\
\hline Aceh Singkil & $43,305,198,369.90$ & $2,851,805,739.00$ & $75,238,699,146.57$ \\
\hline Gayo Lues & $46,277,349,070.00$ & $60,312,455,600.00$ & $48,758,464,130.00$ \\
\hline Nagan Raya & $104,200,297,000.00$ & $74,051,054,000.00$ & $97,118,516,000.00$ \\
\hline Southeast Aceh & $61,457,042,356.11$ & 60.053 .234 .222 .18 & $14,955,587,988.42$ \\
\hline
\end{tabular}

Source: Aceh Province Budget Realization Report

With the realization of the district or city's revenue in Aceh, almost all 23 districts and cities experienced an increase in local revenue. while two cities experienced a decrease in PAD in the realization of the Nagan Raya and Aceh Tenggara budgets. From table 1 above, it can be seen that the realization of PAD in all districts or cities has increased from 2016 to 2018.

Government spending is one of the other supporting factors in increasing local revenue. In general, government spending will increase in line with the increase in economic activity 
of a region. This situation is explained in Wagner's Law, which is about a positive correlation between government spending and the level of national income (Todaro, 2014). In reality, an increase in government spending does not necessarily have a good impact on economic activity, for this, it needs to be reviewed in terms of the efficiency and effectiveness of the use of these government expenditures. To measure the level of efficiency of government spending, it can also be seen from the proportion of routine and development expenditures, as well as the composition of expenditures.

Government spending Aceh Province when viewed from the total indirect expenditure and direct expenditure from 2016 to 2018 can be seen in Graph 1.

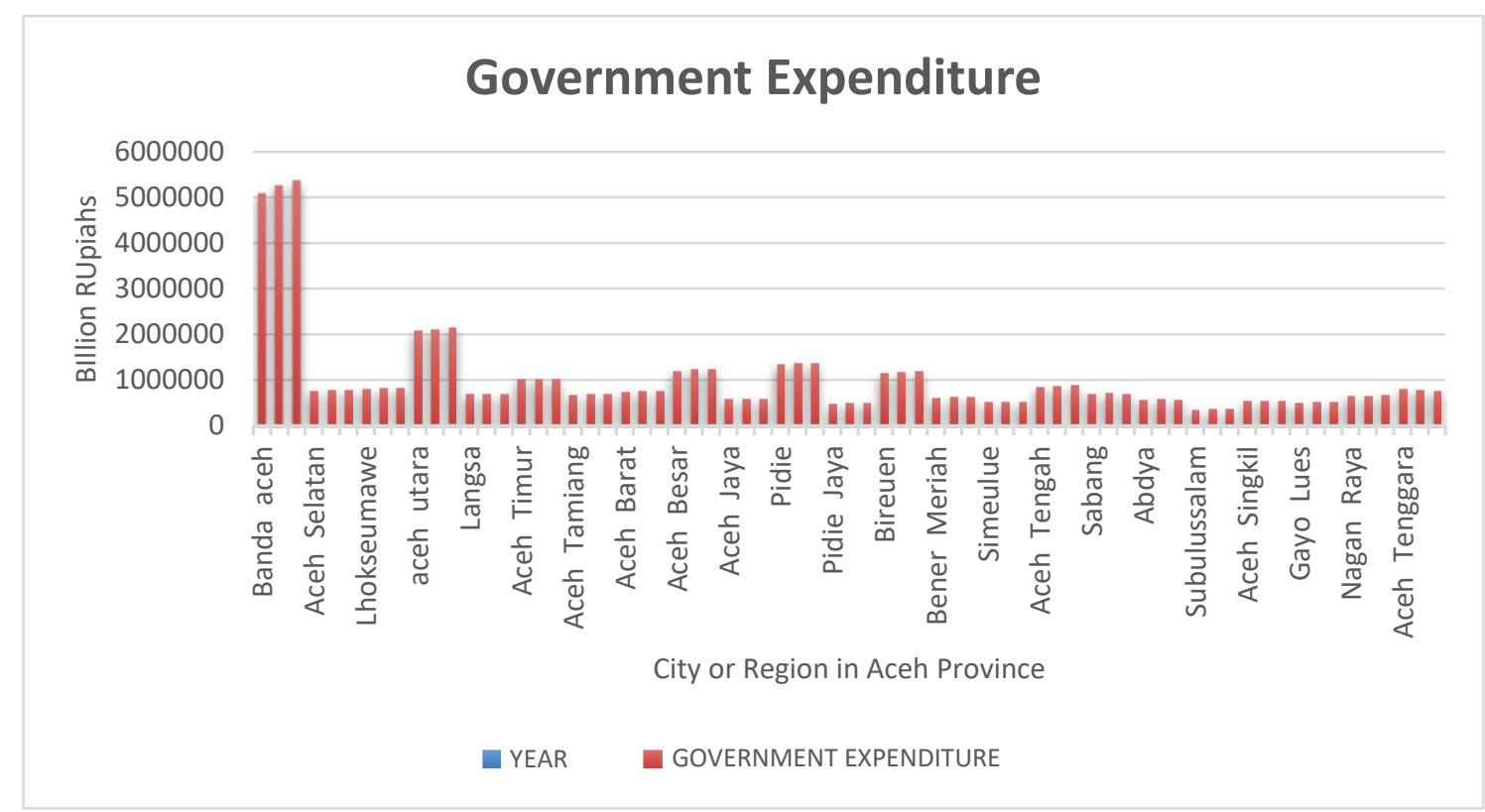

Source: Aceh Province budget realization report

\section{Graph 1. Regency or City Government Expenditure in Aceh 2016-2018 (Billion)}

Aceh provincial government spending from 23 districts or cities in Aceh, 18 of which continued to experience an increase in government spending from 2016 to 2018 . The graph above explains that 2 districts have the largest government expenditure, namely Banda Aceh, North Aceh. It is in line with the data on local revenue which is also large.

Income disparity is the core problem in the implementation of economic development carried out by several poor and developing countries. Regional development aims to prosper the people equally by increasing fast economic growth and reducing the level of income inequality. Population growth that continues to increase and exceeds economic growth will lead to income disparities with regions with more controlled population growth. (Indraja, Deritasari and Hananto, 2014)

Aceh Province has abundant natural resources and also faces problems in the development process, inequality between regions, in this case, districts or cities, due to 
disparities in the origin of natural resources owned and the population in each district or city. Banda Aceh is a city with income per capita, which gave a value of 14.18 million rupiah, when compared to the cities of Sabang, Aceh Besar, Bireuen, Lhokseumawe, Bener Meriah, Aceh Tengah, Aceh Barat, Nagan Raya, and Aceh Selatan. Thus, referring to the GDP per capita, it can be said that most districts/cities in Aceh Province have per capita income that is classified as below average.

Such rapid population growth can cause serious problems for the welfare of society. If the development efforts that have now been implemented will succeed in improving the standard of living of the community which includes the level of income, health, education, and general welfare, then the problem that arises further from the population explosion is the extent to which infrastructure development can provide business opportunities for the community. (Todaro, 2004).

This study aims to determine the determinants of local revenue in the special autonomy era of the Aceh Province government. The hypotheses formulated are as follows: 1. Government expenditure has a positive effect on the regional revenue of Aceh Province 2.PDRB has a positive effect on the regional revenue of Aceh Province 3. The population has a positive effect on the regional revenue of Aceh Province.

\section{Method}

The focus of this research is to analyze the significance of the effect of GRDP, government spending, and total population on local revenue. the research conducted is quantitative. Quantitative research is a study of data in the form of numbers which is then analyzed using statistical methods (Gujarati, 2013).

Location of research is Aceh province. The type of data used in this research is panel data obtained from the Central Bureau of Statistics and LKPD of Aceh Province which consists of data on local revenue, government expenditure, GRDP, and population in districts/cities of Aceh Province which includes data from 2011-2018.The research sample covered 23 districts and cities consisting of Kota Banda Aceh, Pidie, Pidie Jaya, Bireuen, Lhokseumawe, Aceh Utara, Aceh Besar, Aceh Barat, Aceh Timur, Aceh Tengah, Langsa, Aceh Tamiang, Aceh Singkil, Simeulue, Aceh Barat Daya, Aceh Jaya, Aceh Selatan, Aceh Tenggara, Bener Meriah, Gayo Lues, Nagan Raya, Sabang, Subulussalam.

Data analysis in this study uses a quantitative approach, in this study a statistical software tool will be used, namely Stata data is analyzed using panel data regression analysis, with the OLS (Ordinary Least Square) approach using the Common Effect (CEM), Fixed Effect (FEM) model and Random Effect (REM). The formulation of the hypothesis that 
has been stated will be tested using a model (Purbayu, 2005).

$$
\begin{array}{ll}
\text { LnPadit }=\beta 0 \text { it } & +\beta 1 \text { PDRBit }+\beta 2 \text { JPit }+\beta 3 \text { PPit }+ \text { eit } \ldots \ldots \ldots \ldots \ldots \ldots \ldots \ldots \ldots \\
\text { Where: } & \\
\text { LnPAD } & =\text { logarithm of Original Regional Income (Percent) } \\
\text { GRDP } & =\text { Gross Natural Domestic Product (percent) } \\
\text { JP } & =\text { Total population (million people) } \\
\text { PP } & =\text { Government Expenditure (billion rupiah) } \\
\text { i } & =\text { Regency and City } \\
\mathrm{t} & =2011-2018 \text { time } \\
\varepsilon \text { it } & =\text { error term }
\end{array}
$$

Widarjono (2013) explains the advantages of regression using panel data, namely because panel data is a combination of two-time series data and a cross-section, it can provide more data so that it will produce a greater degree of freedom.

According to Widarjono (2007), to estimate model parameters with panel data, there are three techniques (models) that are often used to estimate regression models with panel data, namely, the regression of the estimation of the Common Effect Model (CEM), Fixed Effect Model (FEM), and the approach. Random Effect Model (REM). The purpose of these three methods is to determine the panel regression model that best fits the effect of GRDP, population, government expenditure on local revenue in the District / City of Aceh Province.

To determine the choice of the best model in panel data regression, the Chow test, Hausman test, and Lagrange Multiplier test were performed. The three tests will determine the most appropriate model among the three models, namely the common effect, fixed effect, or random effect.

After choosing the best model, the next step is to test classical assumptions to find out whether there is a violation of the classical assumption test and to obtain a simulator that is Best Linear Unavailable Estimator (BLUE). The classical econometric assumption testing technique according to Widarjono (2013) includes 3 types of tests, namely the multicollinearity test, heteroscedasticity test, and autocorrelation test.

The statistical analysis test was carried out to determine statistically how much significance the influence of the independent variables on the dependent variable either partially or simultaneously. The type of test used is the t-test and F test. Also, it is necessary to calculate the value of the coefficient of determination (R2) to determine the variation of the goodness of fit.

1. Simultaneous Significance Test (Test Statistic F)

The F statistical test shows whether all the independent variables included in the model 
affect simultaneously the dependent variable by using the following hypothesis:

a. Establish a hypothesis.

In this test, the hypothesis being tested is as follows.

H0: $\beta_{1}=\beta_{2}=\ldots=\beta_{\mathrm{k}}=0$, it means that the independent variables together have no statistical effect on the dependent variable.

Ha: at least one of $\beta_{\mathrm{k}} \neq 0$ where $\mathrm{k}=1,2,3, \ldots, \mathrm{k}$, means that the independent variables together have a statistical effect on the dependent variable.

b. Find $\mathrm{F}$ count and critical $\mathrm{F}$ values from the distribution table $\mathrm{F}$.

$\mathrm{F}$ count $=\mathrm{R} 2 /(\mathrm{k}-1)$

1-R2 / (nk)

Where:

$\mathrm{R} 2$ = coefficient of determination

$\mathrm{n} \quad$ number of samples

$\mathrm{k} \quad=$ number of parameters estimated

c. Compares the calculated $\mathrm{F}$ value with the critical $\mathrm{F}$ from the table

If $\mathrm{F}$ count> F critical, $\mathrm{HO}$ is rejected, meaning that the independent variable simultaneously affects the dependent variable. This test can also be done by comparing the p-value with $\alpha$ set. If the $\mathrm{p}$-value $<\alpha, \mathrm{H} 0$ is rejected. This means that the independent variables simultaneously affect the dependent variable (Widarjono, 2013: 67).

2. Partial Test (T-test)

A partial test (T-test) was used to test the effect of each independent variable used in this study on the dependent variable partially.

a. Establish a hypothesis.

The hypothesis tested is as follows.

$\mathrm{H} 0: \beta \mathrm{i}=0$, it means that the independent variable does not statistically influence the dependent variable.

Ha: $\beta i \neq 0, \quad$ means the independent variable has a statistical effect on the dependent variable.

b. Calculate the value of $t$ and look for the critical $t$ value from the $t$ distribution table.

The t-count formula is:

$\mathrm{t}-\mathrm{count}=\left(\beta \mathrm{i}-\beta \mathrm{i}^{*}\right) / \mathrm{SE}(\beta \mathrm{i})$

Where :

$\beta \mathrm{i}=$ the coefficient of the independent variable ith

$\beta \mathrm{i}^{*}=$ null hypothesis value 
SE $(\beta i)=$ standard deviation of the $\mathrm{i}$-th independent variable

c. Comparing the $t$ value for each estimator with the critical $t$ from the table. If $t$ count $>t$ table, $\mathrm{HO}$ is rejected. This means that the independent variables tested partially significantly affect the dependent variable. This test can also be done by comparing the $\mathrm{p}$-value withaset. If the $\mathrm{p}$-value $<\alpha, \mathrm{H} 0$ is rejected. This means that the independent variables tested significantly affect the dependent variable (Widarjono, 2013).

3. Determination Test (R2)

To measure the suitability of a regression equation model for more than two variables, the R2 test or the coefficient of determination is used. This coefficient explains how much the percentage of the dependent variable can be explained by the independent variables in the model together.

Value of $\mathrm{R}^{2}$ ranges from $0<\mathrm{R} 2<1$, the greater the $\mathrm{R} 2$ value (close to 100 percent) the better the regression model. The R2 value of zero means that the variation of the dependent variable cannot be explained at all by the independent variable (Widarjono, 2013)

\section{Results}

To determine the best model, the following Table 2 is presented. To determine the best model we will use Chow Test and Hausman Test.

Table 2. Test results using CEM, FEM REM

\begin{tabular}{lcccccc}
\hline Variable & \multicolumn{2}{c}{$\begin{array}{c}\text { Common Effect } \\
\text { Model }\end{array}$} & \multicolumn{2}{c}{ Fixed Effect Model } & \multicolumn{2}{c}{$\begin{array}{c}\text { Random Effect } \\
\text { Model }\end{array}$} \\
\cline { 2 - 7 } & Coefficient & Prob & Coefficient & Prob & Coefficient & Prob \\
\hline $\begin{array}{l}\text { Government } \\
\text { Expenditure }\end{array}$ & 1.34 & 0.033 & 6.22 & 0.037 & 1.32 & 0.215 \\
\hline GRDP & 0.49 & 0.001 & 2.30 & 0.000 & 0.65 & 0.007 \\
\hline Total population & 8.08 & 0.283 & 0.0000337 & 0.000 & 7.73 & 0.543 \\
\hline
\end{tabular}

Source: processed data

The Chow test is carried out using F restricted, namely by comparing the probability value $\mathrm{F}$ results of the FEM output with a significance level of 0.05 . Hypothesis test for the chow test:

$$
\begin{aligned}
& \text { H0 }=\text { Common Effect Model } \\
& \text { H1 }=\text { Fixed Effect Model }
\end{aligned}
$$

The criteria for rejection of $\mathrm{H} 0$ are if the prob F value is smaller than $\mathrm{H} 1=0.05$, then reject $\mathrm{H} 0$. The following is the Chow test results from the estimation using $\mathrm{F}$ restricted (Table 3 ) The probability value of $\mathrm{F}$ is smaller than $\alpha=0.05$ so that $\mathrm{H} 0$ is rejected, then the chosen model is the Fixed Effect Model. 
Table 3. Chow Test Results

\begin{tabular}{ccc}
\hline & F test & Prob $>$ F \\
\hline Fixed effect model & F $(22,158) 13.57$ & 0.0000
\end{tabular}

Source: processed data

The Hausman test is carried out to select the Fixed Effect Model or the Random Effect Model regression model. Hypothesis tests for the Hausman test are:

$$
\begin{aligned}
& \mathrm{H} 0=\text { Random Effect Model } \\
& \mathrm{Ha}=\text { Fixed Effect Model }
\end{aligned}
$$

The rejection criterion is $\mathrm{H} 0$ if the prob $\mathrm{F}$ value is smaller than $\alpha=0.05$, then reject $\mathrm{H} 0$. Here are the results of the Hausman test from the estimate. The results of the Hausman test in Table 4 show that the prob $C h \mathrm{i}^{2}$ value is smaller than 0.05 so that $\mathrm{H} 0$ is rejected, meaning that the best estimation model chosen is the fixed effect model.

Table 4. Hausman Test Results

\begin{tabular}{llll}
\hline & Chi2 & Prob> chi2 \\
\hline $\begin{array}{l}\text { Fixed effect model } \\
\text { selected }\end{array}$ & 201.96 & 0.0000
\end{tabular}

Source: processed data

Furthermore, we will examine classic assumption, namely multicollinearity test. Multicollinearity shows that the independent variables have a very strong direct relationship (correlation). Based on Table 5, it is known that all independent variables have a VIF value less than the maximum limit of 10 or a Tolerance value of more than 0.1 so that $\mathrm{H} 0$ is rejected, which means that the independent variable does not show any symptoms of multicollinearity (there is no very strong relationship between the independent variable and the independent variable. others).

Table 5. Coefficient Multicollinearity Test (a)

\begin{tabular}{lcc}
\hline Variable & VIF & $\mathbf{1} /$ VIF \\
\hline Total population & 4.40 & 0.22 \\
\hline GRDP & 4.26 & 0.23 \\
\hline Government Expenditure & 2.11 & 0.47 \\
\hline Mean Vif & & 3.59
\end{tabular}

Source: processed data

The Chow and Hausman test results show the coefficients of each panel data regression using robust fixed effects which are summarized in Table 6 as follows. The t-test is a test to see the effect of each dependent variable. If $\mathrm{t}$-Statistic $>\mathrm{t}$-Table or $\mathrm{p}$-value (Prob) $<\alpha, \mathrm{H} 0$ is rejected. Conversely, if the $\mathrm{t}$-Statistic $<\mathrm{t}$-Table or $\mathrm{p}$-value (Prob) $>\alpha, \mathrm{H} 0$ is accepted. The test 
results using panel data regression shows the test results of 0.037 for government spending with a significance level of $0.00(<0.05)$, then $\mathrm{H} 0$ is rejected. Panel data regression shows the test results of 0.00 for GRDP with a significance level of $0.00(<0.01)$, then $\mathrm{H} 0$ is rejected. Panel data regression shows the test results of 0.00 for the population with a significance level of $0.00(<0.01)$, then $\mathrm{H} 0$ is rejected.

Table 6. Fixed Effect Model for PAD Dependent Variables

\begin{tabular}{lcccc}
\hline Variable & Coefficient & $\mathbf{t}$ & $\mathbf{P}>|\mathbf{t}|$ & Information \\
\hline Constant & -18.05 & -3.09 & 0.002 & - \\
\hline $\begin{array}{l}\text { Government } \\
\text { Expenditure }\end{array}$ & 6.222 & 2.11 & 0.037 & Significant \\
\hline GRDP & 2,308 & 5,59 & 0.000 & Significant \\
\hline Total population & 0.00003 & 8.93 & 0.000 & Significant \\
\hline R2 & & & 0.3501 & \\
Prob> F & & 0.0000 & \\
Model & & & Fixed effect & \\
\hline
\end{tabular}

Source: Attachments, processed data

The $\mathrm{F}$ test was conducted to determine whether the independent variables simultaneously had a significant effect or not on the dependent variable. In the fixed-effects model, the test model is by comparing the F-stat with the chi-square table value and the significance level prob> F. For the rejection of $\mathrm{H} 0$, the null hypothesis will be rejected if the F-stat value is greater than the F-table value or if prob> F is more small of $\alpha=0.05$. The following is a table of simultaneous test results (Test F). Based on Table 9, it is known that the F test produces an F-stat value of 93.30 with a probability of 0.0000 . The prob> F value is smaller than $\alpha=0.05$ means that it is statistically significant. This means that the variables of government expenditure, GRDP, and population together or simultaneously have a significant effect on the dependent variable, namely local revenue.

Table 7. Simultaneous Test Results

\begin{tabular}{lccc}
\hline Model & F-stat & Prob> F & Information \\
\hline Fixed Effect Model & $(3.158)=93.30$ & 0.000 & Significant \\
\hline
\end{tabular}

Source: processed data

The multiple determination coefficient $\left(\mathrm{R}^{2}\right)$ is a value that describes how much variation of the dependent variable can be explained by the independent variable. The coefficient of determination is equal to 0 , meaning that the variation of the dependent variable can be explained by the independent variable at all. . The following is a table of $\mathrm{R}^{2}$ results. The regression results in Table 8 show the coefficient of determination $\left(\mathrm{R}^{2}\right)$ of 0.35 or 35 percent. The conclusion is that the independent variables, namely government expenditure, GRDP, and total population can explain the local revenue variable by 35 percent and the remaining 
65 percent is explained by other variables not included in the equation.

Table 8. Results of the coefficient of determination (R2)

\begin{tabular}{lc}
\hline Model & R-Squared \\
\hline Fixed Effect Model & 0.3501 \\
\hline
\end{tabular}

Source: processed data

\section{Discussion}

\section{The Effect of Government Expenditures on Local Own Revenue}

Regional Original Income (PAD) is revenue obtained by the region and collected based on regional regulations under statutory regulations. Original Regional Revenue is regional income that comes from regional taxes, local retribution, the results of separated regional wealth management, and other legal regional income. As for supporting local government programs and community welfare, it is necessary to look at several supporting factors in increasing PAD including Government Expenditure, GRDP, and Total Population.

The results showed that local government spending in Aceh Province in the 2011-2018 period had a positive and significant impact on local revenue. The individual significance test shows that the coefficient of government spending in the selected model is 6.22 and significant at $5 \%$ alpha. This means that government spending of 1 billion will increase local revenue by an average of 6.22 percent while another variable does not move in Aceh Province.

These results are under previous researchers conducted by Rahayu and Santosa (2005), based on empirical studies that have been conducted, in Kediri, it is suggested that government spending has a significant effect on local revenue, where every increase of one unit of government expenditure will be followed. by increasing regional original income. The relationship between PAD and government spending is functional because increasing government spending will increase local revenue to finance development programs. The increase in government spending can encourage an increase in local government services to the community which is expected to increase their productivity.

MS, Zahari (2017) said that proportional government spending will increase economic growth and local revenue. The relationship between economic growth and government spending is an important subject to analyze. Public spending, namely physical infrastructure or human capital, can enhance growth. A large increase in government spending does not necessarily have a good impact on economic activity, so it needs to be viewed with the efficiency of the use of government spending. Measuring the efficiency of government spending can be seen from the proportion of routine expenditures from the composition of expenditures. 


\section{The influence of GRDP on Regional Original Income}

The results showed that PDRB in Aceh Province in the 2011-2018 period had a positive and significant impact on local revenue. The individual significance test shows that the GRDP coefficient in the selected model is 2.30 which is significant at $1 \%$ alpha. This means that an increase in PDRB of 1 percent will increase local revenue by an average of 2.30 percent of ceteris paribus in Aceh Province. It can be concluded that if the GRDP in Aceh Province during the 2011-2018 period has shown a positive and significant impact on local revenue.

These results are consistent with previous researchers conducted by Rahayu and Santosa (2005), Muchtolifah (2010), and Perwira. JG and Putu (2010). based on empirical studies that have been conducted, it is generally suggested that the GRDP has a significant effect on local revenue, where every time there is an increase in one unit of GRDP, it will be followed by an increase in regional original income. The relationship between PAD and GRDP is functional because GRDP is a function of PAD. With the increase in PDRB, it will increase local government revenue to finance development program applications. Furthermore, it will encourage an increase in local government services to the community which is expected to increase their productivity.

\section{The Influence of Total Population on Local Revenue}

The results showed that the total population in Aceh Province in the 2011-2018 period had a positive and significant impact on local revenue. The individual significance test shows that the population coefficient in the selected model is 0.0003 significant at apha1\%. This means that every increase in population by 1 percent will increase local revenue by an average of 0.003 percent ceteris paribus in Aceh Province. It can be concluded that the total population in Aceh Province during the 2011-2018 period has shown a positive and significant impact on local revenue.

These results are under previous researchers conducted by officers. JG and Putu (2010). based on empirical studies that have been conducted, it generally suggests that the total population has a significant influence on local revenue, where each increase of one person will be followed by an increase in local revenue. A productive population is the hope of the local government, the more productive the population, the greater the job opportunities created, besides that the number of people who are balanced with educated human resources will help build a local government. Therefore, the population determines the economy in the regional and central government. Based on the results of the research, the three variables, namely government expenditure, population, and GRDP, have an effect on 
local revenue in Aceh province 2011-2018.

\section{Conclusions and Suggestions}

This study concludes that government expenditure, GRDP, and individual population have a positive effect on local revenue in Aceh Province in the 2011-2018 period. Together, government expenditure, GRDP, and total population have a positive effect on local revenue in Aceh Province. in the period 2011-2018 / as for the suggestions that can be conveyed from the results of this study are:

The commitment of the Aceh government in prioritizing public investment must be further enhanced considering that the ratio of regional government capital expenditures to total district or city government expenditures in Aceh is not sufficient to spur efforts to improve community welfare because capital expenditures and routine expenditures will spur regional development in Aceh and have a real impact on needs. development in Aceh Province.

\section{REFERENCE}

Abba, M. d., 2015. Expenditure and Internally Generated Revenue Relationship: An Analysis of Local Governments in Adamawa State, Nigeria. International Refereed Research Journal, 6(3), p. 1.

Aceh, P. K. P., 2007. Mengukur Kinerja Pemerintah Daerah di Aceh. [Online] Available at: http:siterources.worldbank.org/INTINDONESIA/Publication/ 2800161168483675167/PFM_Aceh_fullbhs.pdf [Accessed 2 Januari 2018].

Aceh, S. A. P. W. P., 2015. Analisis Pembangunan Wilayah Provinsi Aceh. [Online].

Aslim, d., 2014. Analisis Faktor-Faktor Yang Mempengaruhi Pendapatan Asli Daerah Kota Banda Aceh. Ilmu Ekonomi: Pascasarjana Universitas Syiah Kuala, 2(3), pp. 60-66.

Badan Pusat Statistik, B., 2011. Jumlah Penduduk dan PDRB Per Kapita Kabupaten/Kota Provinsi Aceh. [Online] Available at: http://bps.go.id

Badan Pusat Statistik, B., 2014. Laporan Realisasi Anggaran Provinsi Aceh: Pendapatan Asli Daerah Kabupaten/Kota Provinsi Aceh. [Online] Available at: http://bps.go.id

Badan Pusat Statistik, B., 2015. Laporan Realisasi Anggaran Provinsi Aceh: Pendapatan Asli Daerah Kabupaten/Kota Provinsi Aceh. [Online] Available at: http://bps.go.id Gujarati, D., 2013. Dasar-Dasar Ekonometrika Edisi Kelima. 5th ed. Jakarta: Salemba Empat. Halim, A., 2016. Manajemen Keuangan Sektor Publik: Problematika Penerimaan dan Pengeluaran Pemerintah. Jakarta: Salemba Empat. 
Hamzah, d., 2017. Analisis Pengaruh Pertumbuhan Ekonomi dan Pengeluaran Pemerintah Aceh Terhadap Pendapatan Asli Daerah Provinsi Aceh Setelah Tsunami. Ekonomi dan Kebijakan Publik Indonesia, 4(1), pp. 1-12.

Jaya, G. B. P. \& Putu, W. A. B., 2014. Analisis Faktor-Faktor yang Berpengaruh Terhadap Pendapatan Asli Daerah (PAD) Kota Denpasar. EP Universitas Udayana, 3(5), pp. 201208.

Moengkoesoebroto, G., 2016. Ekonomi Publik. Yogyakarta: BPFE Yogyakarta.

MS, Z., 2017. Pengaruh Pengeluaran Pemerintah Terhadap Pertumbuhan Ekonomi di Provinsi Jambi. Jurnal of Economics and Business, 1(1).

Muchtolifah, 2010. Analisis Beberapa Faktor Yang Mempengaruhi Pendapatan Asli Daerah (PAD) di Kota Surabaya. Ilmu Ekonomi Pembangunan, 1(2).

Nto, P. O., 2016. Assesment of Risk in The Internally Generated Revenue (IGR) Structure of Abia State, Nigeria. Canadian Social Science, 12(3), pp. 67-72.

Parwata, I. M. d., 2016. Pengaruh Produk Domestik Regional Bruto (PDRB) dan Tingkat Pengangguran Terbuka Terhadap Tingkat Kemiskinan. Bisma Universitas Pendidikan Ganesa Jurusan Manajemen, Volume 4.

Rachim, A., 2015. Analyzing Local Revenue in Local Otonomy Implementations Towards Self-Relience of Samarinda Municipality. International Journal Business Management and Economic Rrsearch (IJBMER), 6(6), pp. 436-441.

Sagun, O. P., 2014. Federal Government Statutory Fund Allocation to States in Negeria, West Africa: Any Reasonable Story to Tell?. American International Journal of Social Science, 3(4), pp. 152-164.

Santoso, P. B. d. R. P., 2005. Analisis Pendapatan Asli Daerah (PAD) dan Faktor-Faktor Yang Mempengaruhinya Dalam Upaya Pelaksanaan Otonomi Daerah di Kabupaten Kediri. Dinamika Pembangunan, 2(1), pp. 9-18.

Sasana, H., 2006. Analisis Dampak Desentralisasi Fiskal Terhadap Pertumbuhan Ekonomi di Kabupaten/Kota Provinsi Jawa Tengah. Dinamika Pembangunan, 3(2), pp. 145-170.

Sidik, D. M., 2002. Format Hubungan Keuangan Pemerintah Pusat dan Daerah Yang Mengacu Pada Pencapaian Tujuan Nasional. 17-18 April.

Susanti, H., Syechalad, M. N. \& Hamzah, A., 2017. Analisis Pengaruh Pertumbuhan Ekonomi dan Pengeluaran Pemerintah Aceh Terhadap Pendapatan Asli Daerah Provinsi Aceh Setelah Tsunami. Ekonomi dan Kebijakan Publik Indonesia, 4(1), pp. 1-12.

Todaro, M. P., 2014. Economic Development. 12th ed. New York: Pearson.

Undang-Undang Nomor 5 Tahun 1974 Tentang Pokok-Pokok Pemerintahan di Daerah. Undang-Undang Nomor 9 Tahun 2015 Tentang Pemerintahan Daerah. 
Undang-Undang Nomor 28 Tahun 2009 Tentang Pajak Daerah dan Retribusi Daerah.

Undang-Undang Nomor 32 Tahun 2004 Tentang Pemerintahan Daerah.

Undang-Undang Nomor 33 Tahun 2004 Tentang Perimbangan Keuangan Antara Pemerintah Pusat dan Pemerintah Daerah.

Widarjono, A., 2013. Ekonometrika: Pengantar dan Aplikasinya. Jakarta: Ekonosia. 